\title{
床反カからみた全身の急速反復功作の発達
}

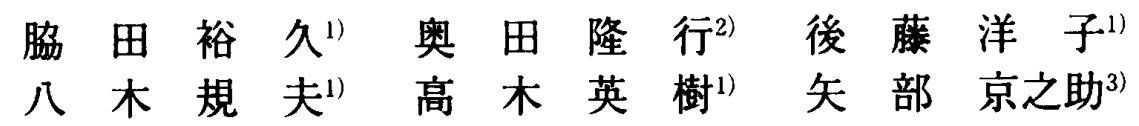

\section{Development of a rapidly repeating movement of the whole body.}

\author{
Hirohisa Wakita ${ }^{1}$ Takayuki Okuda ${ }^{2}$ Yoko Goto $^{1}$ Norio Yagi ${ }^{1}$ \\ Hideki Takagi ${ }^{1}$ and Kyonosuke Yabe $^{3}$
}

\begin{abstract}
The present study was designed to investigate the development of a rapidly repeating movement of the whole body from ground reaction forces exerted during a side jump. Subjects were 246 healthy males aged 5-17 years, and their physique (body height, body mass, skinfold thickness), muscular power (vertical jump, standing broad jump) and rapidly repeating movement (stepping, side jump) were measured.

The procedure of the side jump were hopping between two parallel lines on the force plate from right to left alternately as quickly as possible. The distance between the lines was fixed at one third of the mean body height at each age. Force curves gained by using force plate were calculated using the jumping frequency per 1 second (the frequency calculated from the time required for one jump), the times on the ground and in the air, the maximum vertical and horizontal forces, the vertical and horizontal impulses and the kicking angle caluculated from maximum vertical and horizontal forces.

The frequency of the side jump per 1 second increased significantly with age by 11 years. The time on the ground shortend significantly with age by 10 years. The time in the air shortened significantly with age by 7 years. The maximum vertical force per unit body mass did not change remarkably with age, but the maximum horizontal force per unit body mass increased significantly with age by 12 years. The kicking angle decreased significantly with age by 12 years. The vertical impulse per unit body mass decreased significantly with age by 11 years, but the horizontal impulse per unit body mass did not change remarkably with age.

These results suggest that a rapid repeating ability of the whole body develops by increasing the horizontal force in compairison with vertical force and by decreasing the kicking angle and the vertical displacement of the center of gravity with age by about 12 years.
\end{abstract}

Key words : agility, repeating movement, ground reaction force, development

(Japan J. Phys. Educ., 38 : 459-468, March, 1994.)

1）三重大学教育学部 于514 三重県津市上浜町 1515

2) 三重県立津高等学校 $\overline{\mathbf{T}} 514$ 三重県津市新町 3 丁目

3) 名古屋大学棇合保険体育科学ヒンター 于464 名古屋市千種区不老町
1. Mie University. Faculty of Education. Kamihama-cho. Tsu. Mie (514)

2. Tsu Senior High School Shinmachi Tsu. Mie (514)

3. Research Center of Health, Physical Fitness and Sports, Nagoya University, Furou-cho, Chikusa-ku. Nagoya (464) 


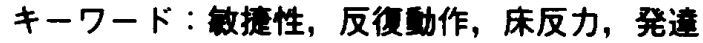

$$
\text { 【目的】 }
$$

体力要素のひとつである敏捷性の能力は，与え られた刺激に対して反応動作が起こるまでの時間 や一定時間内の反復頻度によって測定されてい る. 後者の反復頻度の測定には, 局所動作の tapping・ stepping, 全身動作の side step $\cdot$ side jump $\cdot$ jump step test $\cdot$ burpee test $\cdot$ shuttle run などがある.

局所動作の tapping は, 反復頻度を指標とした 加龄的変化·幼坚と成人の動作比較·時間経過にと もなう疲労などが検討され $れ^{3.5 .6 .9 .16 .18 .19)}$, stepping については反復頻度を用いた加龄的変化・一 般人と一流選手の比䡈・測定中の時間経過にとも なう変化などが報告されている ${ }^{10,11.18 .22 .23 .26) . ~}$

一方，全身動作の jump step test は，大学生男 子を対象とした動作分析や生理学的な検討がなさ れてきたが15)，その方法は一般的なものとして 定着していない，体力診断テスト項目として普及 している side step は, 反復頻度を指標とした加 龄的変化・測定時間の検討・測定にともなう心拍 数の変化 ${ }^{20.24)}$ などが報告されている．また，幼 児にとっては, side step の動作が複雑であるこ となどから，幼児用のテスト・マニュアルを作成

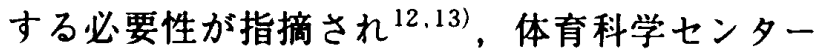
調整力委員会によって side jump が考案され，そ の実施要領と基準値が提示されている ${ }^{21)}$. 幼览 の side jump に関する研究は，様々なテスト間の 成績を比較した測定法の検討 ${ }^{1,2)}$ - 調整力を向上 させるためのトレーニング効果の検討 ${ }^{7,14)}$ ・ side jump の反復頻度と床反力の関係 ${ }^{17)}$ などが報告さ れている.しかし, side jumpの加龄的変化に関 して運動学的な視点から検討を加えた報告はこれ までに見受けられない。

本研究は，発育期にある 5-17歳の男子を対象 に, side jump 中に発揮された床反力曲線を指標 として，全身的な急速反復動作の発達過程および 各年龄における全身的な急速反復動作の素早さの 要因を検討することをその目的とした。

\section{【研究方 法】}

被検者は，5-17歳の健常な男子246名を対象 とし，形態 (身長・体質量・皮下脂肪厚)，瞬発 力（垂直跳び・立ち幅跳び：両跳躍とも反動を用 いないようにして実施)，敏捷性（stepping・side jump）を测定した（Table 1).

stepping の測定は，被検者に椅座位姿势をとら せ，検者の「始め」の合図の後10秒間，両足をで きる限り素早く force plate 上で踏み換える動作

Table 1. Physical characteristics of subjects.

\begin{tabular}{|c|c|c|c|c|c|c|c|c|c|c|c|c|c|}
\hline Age $(\mathrm{yr})$ & 5 & 6 & 7 & 8 & 9 & 10 & 11 & 12 & 13 & 14 & 15 & 16 & 17 \\
\hline Number of subjects & 21 & 18 & 16 & 19 & 17 & 18 & 16 & 20 & 20 & 21 & 20 & 20 & 20 \\
\hline \multirow[t]{2}{*}{ Body height $(\mathrm{cm})$} & 110.4 & 118.3 & 123.9 & 127.7 & 136.9 & 139.1 & 143.4 & 150.7 & 160.2 & 163.5 & 170.7 & 169.7 & 170.2 \\
\hline & 4.95 & 5.88 & 6.50 & 4.72 & 3.91 & 3.50 & 5.73 & 8.17 & 6.96 & 6.74 & 4.98 & 4.68 & 4.19 \\
\hline \multirow[t]{2}{*}{ Body mass $(\mathrm{kg})$} & 19.1 & 22.3 & 24.7 & 26.4 & 30.4 & 34.6 & 36.8 & 41.4 & 49.7 & 50.7 & 59.4 & 56.2 & 58.1 \\
\hline & 2.12 & 2.61 & 4.48 & 3.71 & 4.00 & 5.77 & 5.85 & 7.20 & 8.68 & 6.47 & 10.55 & 7.43 & 8.22 \\
\hline \multirow[t]{2}{*}{ Skinfold thickness (mm) } & 17.2 & 17.2 & 18.2 & 19.6 & 19.6 & 24.9 & 26.2 & 22.2 & 18.7 & 17.4 & 22.6 & 17.0 & 20.9 \\
\hline & 4.41 & 3.39 & 7.74 & 4.67 & 8.74 & 12.68 & 12.44 & 6.31 & 9.64 & 7.36 & 14.11 & 7.12 & 11.58 \\
\hline \multirow[t]{2}{*}{ Vertical jump $(\mathbf{c m})$} & 21.1 & 23.0 & 22.6 & 27.7 & 31.3 & 36.1 & 37.9 & 39.9 & 48.4 & 48.2 & 53.7 & 53.6 & 53.3 \\
\hline & 3.86 & 3.91 & 4.02 & 5.26 & 5.59 & 5.91 & 8.75 & 6.58 & 8.61 & 4.16 & 8.06 & 3.96 & 9.03 \\
\hline \multirow[t]{2}{*}{ Standing broad jump $(\mathrm{cm})$} & 105 & 121 & 125 & 140 & 152 & 153 & 173 & 190 & 193 & 194 & 200 & 209 & 197 \\
\hline & 9.3 & 15.7 & 23.4 & 10.6 & 8.8 & 9.5 & 16.6 & 22.6 & 18.0 & 16.6 & 21.8 & 16.4 & 19.6 \\
\hline \multirow[t]{2}{*}{ Stepping (times/sec) } & 3.02 & 3.50 & 3.56 & 4.22 & 5.05 & 5.07 & 4.73 & 5.12 & 5.68 & 5.44 & 6.07 & 5.42 & 6.08 \\
\hline & 0.55 & 0.43 & 0.49 & 0.86 & 0.65 & 0.58 & 0.49 & 0.78 & 0.62 & 0.63 & 0.64 & 0.58 & 0.59 \\
\hline
\end{tabular}


を行わせた．反復頻度は，force plate から導出さ れた床反力曲線（鉛直分力）から 1 秒間における 一側肢の反復頻度を求めた。

side jump の測定は，体育科学センター調整力 委員会による side jumpの実施要領に準拠し た ${ }^{21)}$. 被検者には，force plate 上に引かれた 2 本の平行な右側のライン上に右足をのせた準備姿 势をとらせ，検者の「始め」の合図とともに両足 踏切りで右足が左側のラインを踏むか踏み越す跳 躍動作を交互にできる限り素早く行わせた。これ までに，反復頻度の最大あるいはそれに近い状態 は, 動作開始後 $2-5$ 秒間しか持続しないことが

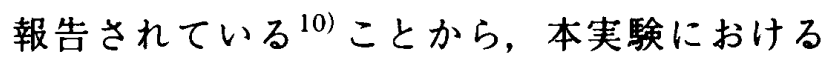
side jump の測定時間は 5 秒間に設定した。また。 ライン幅は，5-11歳までは体育科学センター調 整力専門委員会が提示した基準値に準拠し，1217歳のライン幅は $5-11$ 歳までの基準值が身長の 約 3 分の 1 であったことから，日本人の標準値の 3 分の 1 に設定した ${ }^{23)}$ (Table 2). force plate から導出された床反力曲線は，鉛直 分力と水平分力が記録できるようにし，反復動作 中の比僌安定した素早い 4 試行を抽出し，その平 均値を個人值とした。分析項目は, 着床時間（着 床から踏切までの時間), 離床時間（踏切から着 床までの時間), 鉛直分力 (鉛直分力の最大値), 水平分力 (水平分力の最大值)，力積の鉛直成分 と水平成分を計測した。また，キック角度は，鉛 直分力と水平分力を合成し，水平面からの角度を 算出した（Fig.1）。なお，加龄的変化に関する統 計処理は， $\mathrm{t}$ 検定を用いて検討した。

\section{【結果】}

side jump 中に発揮された床反力曲線の分析に よる各年龄毎の平均値を Table 2 に示した。

\section{1. 反得㛲度}

反復頻度は，着床時間と離床時間を加えて side jump 1 回に要する時間を求め, この值から

Table 2. The values of ground reaction forces exerted during the side jump.

\begin{tabular}{|c|c|c|c|c|c|c|c|c|c|c|c|c|c|}
\hline Age (yr) & 5 & 6 & 7 & 8 & 9 & 10 & 11 & 12 & 13 & 14 & 15 & 16 & 17 \\
\hline umb & 21 & 18 & 16 & 19 & 17 & 18 & 16 & 20 & 2 & 1 & 0 & 0 & 20 \\
\hline $\begin{array}{l}\text { idth between jumping lines } \\
\qquad(\mathrm{cm})\end{array}$ & 35 & 37 & 39 & 41 & 43 & 45 & 47 & 50 & 52 & 54 & 6 & 56 & 56 \\
\hline \multirow{2}{*}{$\begin{array}{l}\text { Jumping frequency per sec } \\
\text { (times) }\end{array}$} & 2.20 & 2.47 & 2.71 & 2.89 & 3.07 & 2.97 & 3.41 & 3.04 & 3.29 & 2.87 & 2.97 & 3.20 & 2.80 \\
\hline & 0.27 & 0.18 & 0.26 & 0.46 & 0.33 & 0.29 & 0.39 & 0.48 & 0.31 & 0.26 & 0.28 & 0.32 & 0.41 \\
\hline \multirow{2}{*}{$\begin{array}{l}\text { The time on the ground } \\
\qquad(\mathrm{msec})\end{array}$} & 231 & 217 & 194 & 179 & 171 & 171 & 158 & 161 & 154 & 171 & 177 & 158 & 183 \\
\hline & 49.3 & 35.7 & 22.2 & 21.7 & 31.6 & 28.1 & 19.0 & 28.4 & 15.8 & 22.5 & 20.9 & 21.1 & 32.4 \\
\hline \multirow[t]{2}{*}{ The time in the air (msec) } & 223 & 188 & 175 & 167 & 154 & 166 & 135 & 168 & 150 & 177 & 160 & 154 & 175 \\
\hline & 20.1 & 31.7 & 29.5 & 39.9 & 17.9 & 17.1 & 21.6 & 30.1 & 18.9 & 23.1 & 27.8 & 16.9 & 30.2 \\
\hline ertical torce per & 3.76 & 3.74 & 4.31 & 4.11 & 4.67 & 4.87 & 4.40 & 4.18 & 4.05 & 4.35 & 4.14 & 4.00 & 4.18 \\
\hline unit body mass $(\mathrm{kgw} / \mathrm{kg})$ & 0.69 & 0.61 & 0.42 & 0.47 & 0.70 & 1.29 & 0.87 & 0.39 & 0.38 & 0.42 & 0.39 & 0.56 & 0.51 \\
\hline orizontal force per & 0.73 & 0.95 & 1.19 & 1.33 & 1.40 & 1.32 & 1.38 & 1.60 & 1.68 & 1.70 & 1.62 & 1.84 & 1.65 \\
\hline unit body mass $(\mathrm{kgw} / \mathrm{kg})$ & 0.18 & 0.24 & 0.22 & 0.29 & 0.27 & 0.29 & 0.23 & 0.31 & 0.21 & 0.25 & 0.23 & 0.32 & 0.27 \\
\hline \multirow[t]{2}{*}{ Kicking anglc (degree) } & 79.1 & 75.8 & 74.4 & 72.1 & 73.2 & 74.6 & 72.3 & 69.1 & 67.5 & 68.7 & 68.7 & 65.3 & 68.4 \\
\hline & 1.94 & 2.91 & 3.21 & 2.85 & 2.76 & 2.40 & 2.53 & 3.53 & 1.89 & 3.08 & 2.12 & 2.44 & 3.08 \\
\hline Vertical impulse per & 0.482 & 0.420 & 0.380 & 0.369 & 0.365 & 0.360 & 0.304 & 0.328 & 0.312 & 0.346 & 0.349 & 0.312 & 0.361 \\
\hline unit body mass $(\mathrm{kgw} \cdot \mathrm{sec} / \mathrm{kg})$ & 0.057 & 0.057 & 0.038 & 0.052 & 0.058 & 0.036 & 0.037 & 0.071 & 0.030 & 0.035 & 0.037 & 0.039 & 0.060 \\
\hline Horizonal impulse per & 0.080 & 0.097 & 0.097 & 0.096 & 0.091 & 0.099 & 0.094 & 0.121 & 0.122 & 0.138 & 0.113 & 0.121 & 0.115 \\
\hline unit body mass $(\mathrm{kgw} \cdot \mathrm{sec} / \mathrm{kg})$ & 0.020 & 0.014 & 0.012 & 0.014 & 0.026 & 0.009 & 0.009 & 0.017 & 0.017 & 0.019 & 0.014 & 0.023 & 0.019 \\
\hline
\end{tabular}

Upper value is mean.

Lower value is S.D. 

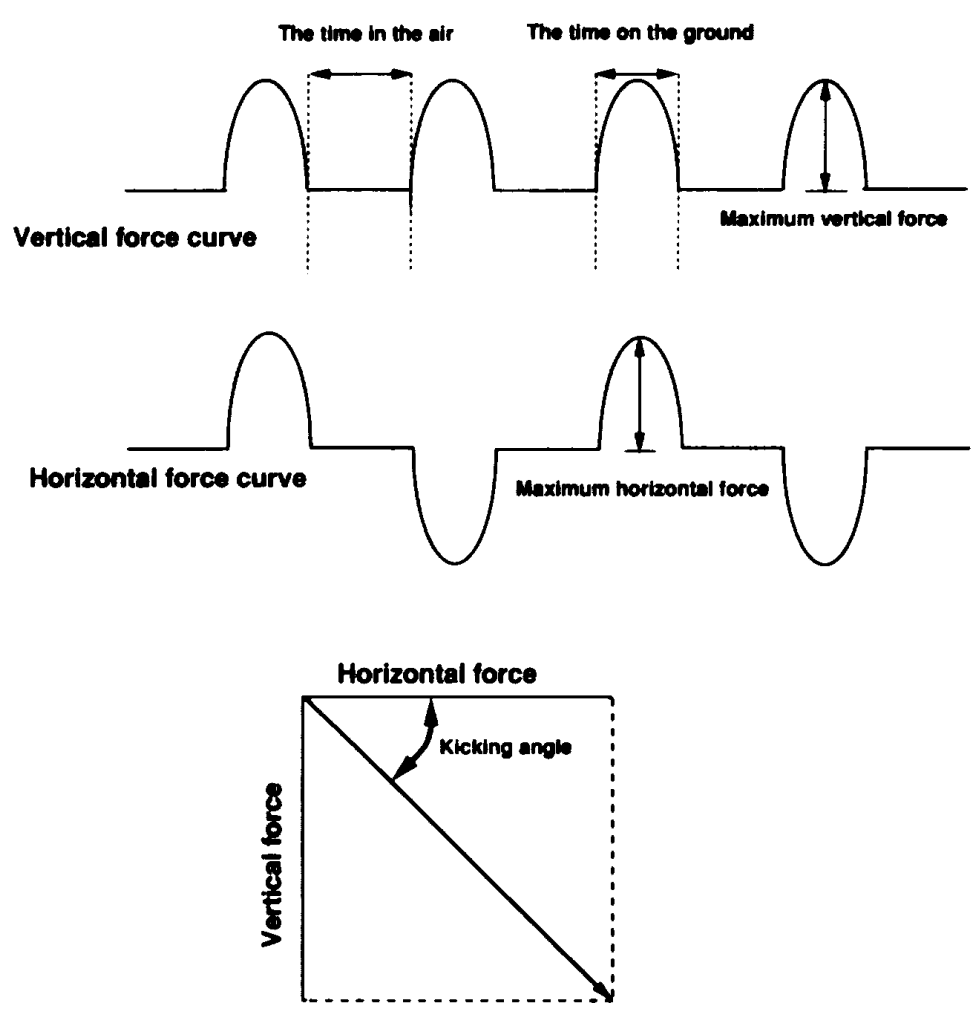

Fig. 1. Analysis of ground reaction forces.

1 秒あたりの反復頻度を算出した。この反復頻度 の平均值は，5 墄 $(2.20$ 回 $/ \mathrm{sec})$ から11歳 (3.41 回 / sec）まで加龄に伴い急激に增加し，5藏と 7 墄, 7 歳と 10 藏, 10 藏と11藏の間にそれぞれ $1 \%$ $-5 \%$ 水準の有意な差が認められた。 その後17墄

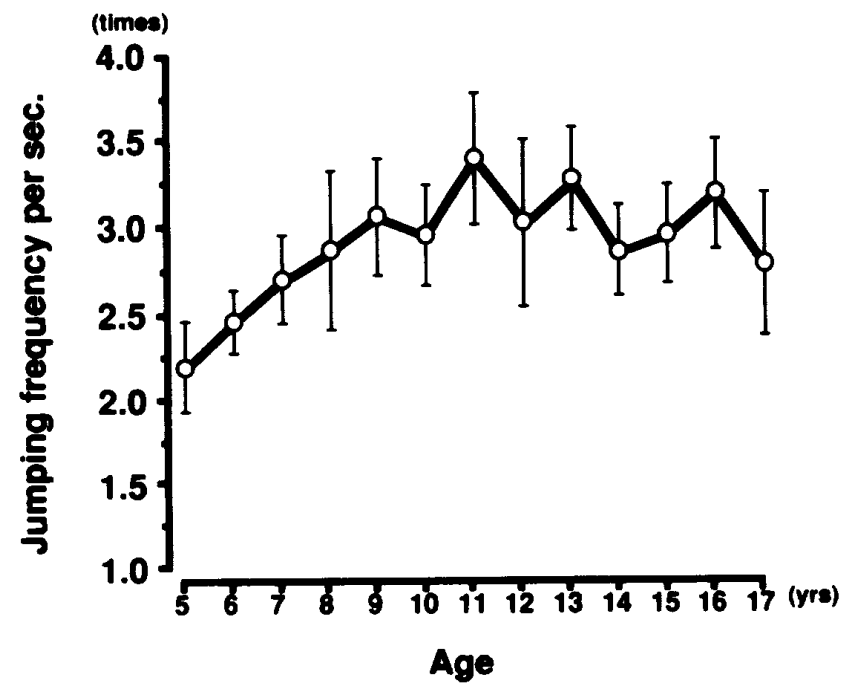

Fig. 2. Developmental change of the jumping frequency per sec.

(white circle : mean, vertical line : s. d.)
（2.80回 sec）までは，ほほ類似した值を示し， 12 歳と 17 歳の間には有意な差が認められなかっ た. 17歳の反復頻度を基準とすると， 5 歳の值は $78.6 \%$ であた（Fig.2）。

\section{2. 首床時问と離床時问}

着床時間の平均値は， 5 歳 $(231 \mathrm{msec})$ から 11 歳 $(158 \mathrm{msec})$ まで加踚に伴い急激に短縮し， 5 歳と 7 歳の間に $1 \%$ 水準， 7 歳と 10 歳の間に $5 \%$ 水準の有意な差が認められた。 その後17歳（183 msec）までは，ほほ類似した值を示し，10歳と 17歳の間には有意な差が認められなかった。17歳 の着床時間を基準とすると, 5 歳の値は約 $126.2 \%$ であった（Fig.3）.

離床時間の平均値は， 5 歳 $(223 \mathrm{msec})$ から 11 歳（135 msec）まで加齢に伴い急激に短縮し， 5 歳と 7 歳の間に $1 \%$ 水準の有意な差が認められ た。 その後17歳 $(175 \mathrm{msec})$ までは，ほほ類似し た値を示し，12嘁と17藏の間には有意な差が認め られなかった．17葴の離床時間を基準とすると， 5 歳の值は127.4\%であった（Fig.4）. 


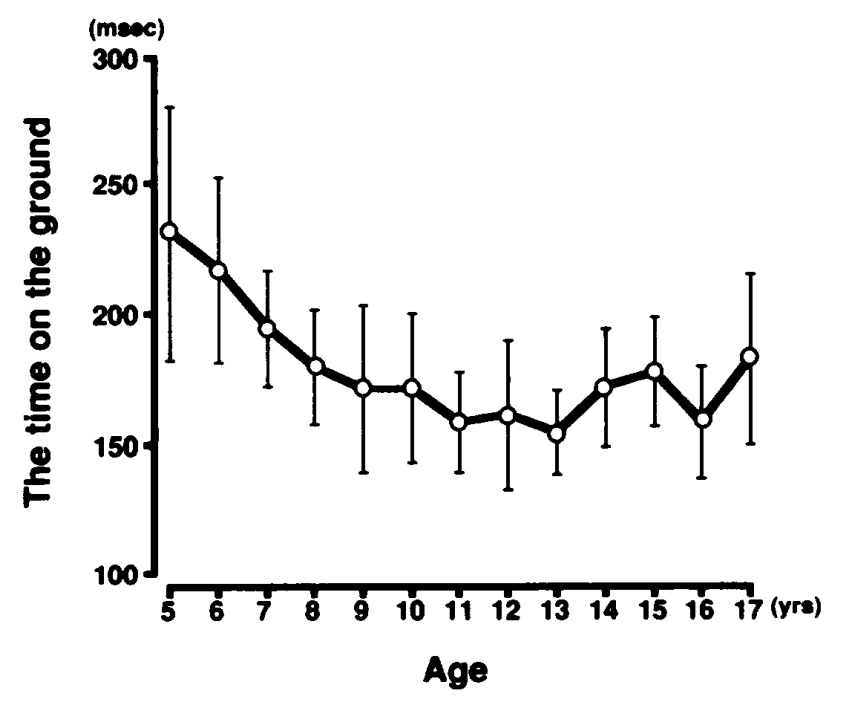

Fig. 3. Developmental change of time on the ground. (white circle : mean, vertical line : $s$. d.)

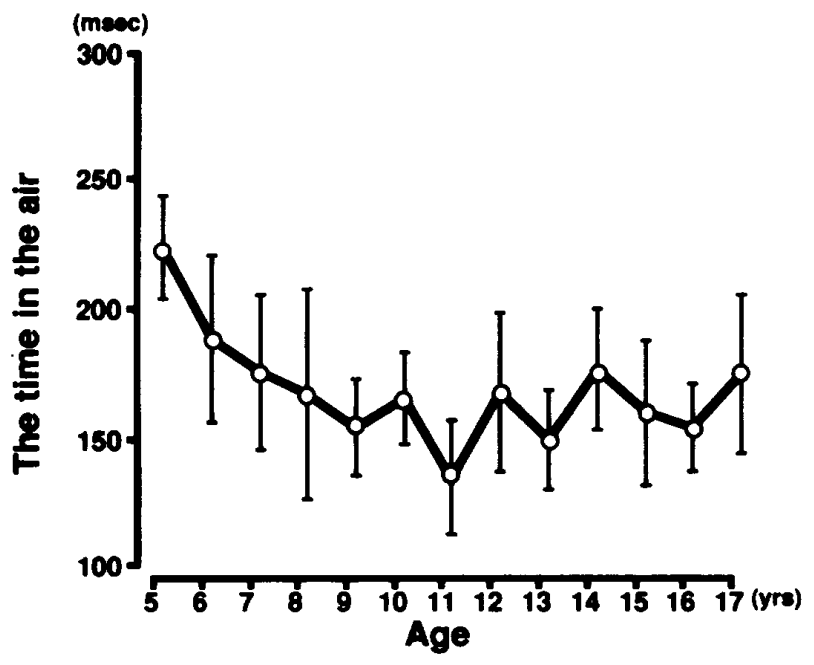

Fig. 4. Developmental change of time in the air. (white circle : mean, vertical line : s. d.)

\section{3. 鉛亩分力と水平分力}

鉛直分力と水平分力の加龄的変化については, 体質量の影勧を消去するために，それぞれの単位 体質量あたりの值に換算して検討した．単位体質 量あたりの鉛直分力の平均値は， 5 歳 (3.76 $\mathrm{kgw} / \mathrm{kg})$ から 17 藏 $(4.18 \mathrm{kgw} / \mathrm{kg})$ にかけて影著 な変化が認められず， 6 藏と 7 歳， 8 歳と 9 歳の 間に $1 \%$ 水準の有意な増加, 10歳と 12 歳の間に $5 \%$ 水準の有意な滅少が認められた。17歳の単位 体質量あたりの鉛直分力を基準とすると， 5 歳の 値は90.0\%であった（Fig.5).

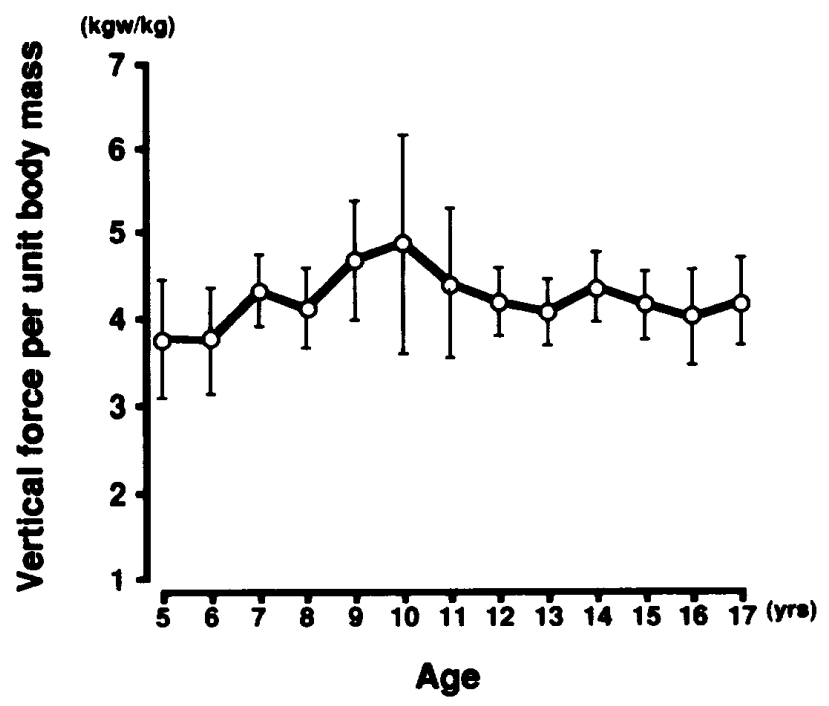

Fig. 5. Developmental change of vertical force per unit body mass.

(white circle : mean, vertical line : s. d.)

単位体犋量あたりの水平分力の平均値は，5歳 $(0.73 \mathrm{kgw} / \mathrm{kg})$ から 12 岀 $(1.60 \mathrm{kgw} / \mathrm{kg})$ にかけ て増加し, 5歳と6歳, 6 歳と 7 歳, 10 歳と 11 歳, 11 歳と 12 歳の間にそれぞれ $1 \%$ 水漸, 7 歳と 9 歳 の間に $5 \%$ 水準の有意な差が認められた。その後 17 歳 $(1.65 \mathrm{kgw} / \mathrm{kg})$ までは, 緩慢な増加であり, 12 歳と 17 歳の間には有意な差が認められなかっ た. 17歳の単位体質量あたりの水平分力を基準と すると，5歳の値は44.2\%であった（Fig.6）.

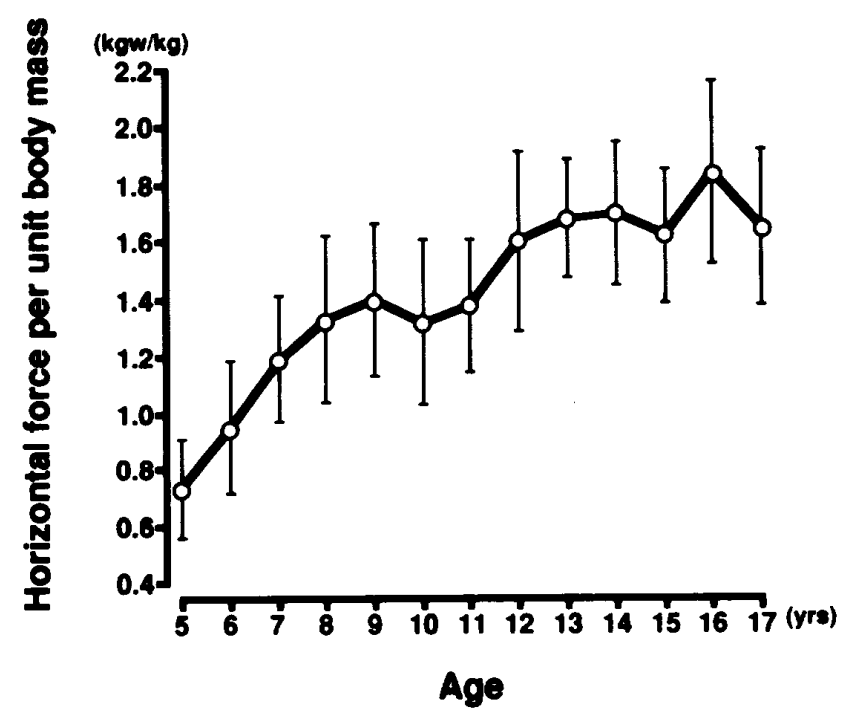

Fig. 6. Developmental change of horizontal force per unit body mass.

(white circle : mean, vertical line : s. d.) 


\section{4. キック角度}

キック角度の平均値は, 5 歳 $\left(79.1^{\circ}\right)$ から 12 歳 $\left(69.1^{\circ}\right)$ にかけて滅少し, 5 歳と 6 歳, 11 墄 と 12 歳の間に $1 \%$ 水準，7歳と 8 歳，10歳と 11 歳 の間に $5 \%$ 水準の有意な差が認められた。 その後 17 歳 $\left(68.4^{\circ}\right)$ までは，緩慢な隇少を示し，12歳 と17歳の間には有意な差が認められなかった。 17 歳のキック角度を基準とすると，5歳の值は 115.6\%であった（Fig.7）。

\section{5. 力䖽}

力積の鉛直成分と水平成分の加龄的変化につい ては，体質量の影響を消去するために，それぞれ の単位体質量あたりに换算して検討した，単位体 質量あたりの鉛直成分の平均値は， 5 歳 $(0.482$ $\mathrm{kgw} \cdot \mathrm{sec} / \mathrm{kg})$ から11歳 $(0.304 \mathrm{kgw} \cdot \mathrm{sec} / \mathrm{kg})$ ま で急激な滅少を示し， 5 藏と 7 歳、7 歳と 11 歳の 間に $1 \%$ 水準の有意な差が認められた．その後 17 歳 $(0.361 \mathrm{kgw} \cdot \mathrm{sec} / \mathrm{kg})$ までは，ほほ類似した 値を示し，12歳と17歳の間には有意な差が認めら れなかった１7歳の単位体質量あたりの鉛直力 積を基準とすると， 5 嵗の值は $133.5 \%$ であった

(Fig.8).

単位体質量あたりの水平成分の平均値は，5藏 $(0.080 \mathrm{kgw} \cdot \mathrm{sec} / \mathrm{kg})$ から 17 歳 $(0.115 \mathrm{kgw}$ ・ $\mathrm{sec} / \mathrm{kg}$ ) までほほ類似した值を示し， 5 歳と12歳

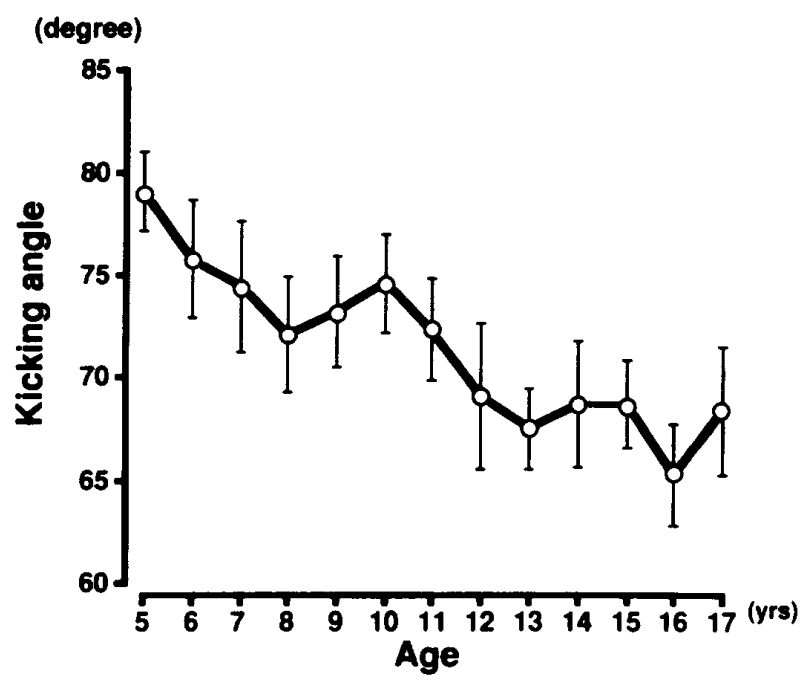

Fig. 7. Developmental change of kicking angle. (white circle : mean, vertical line : $s$. d.)

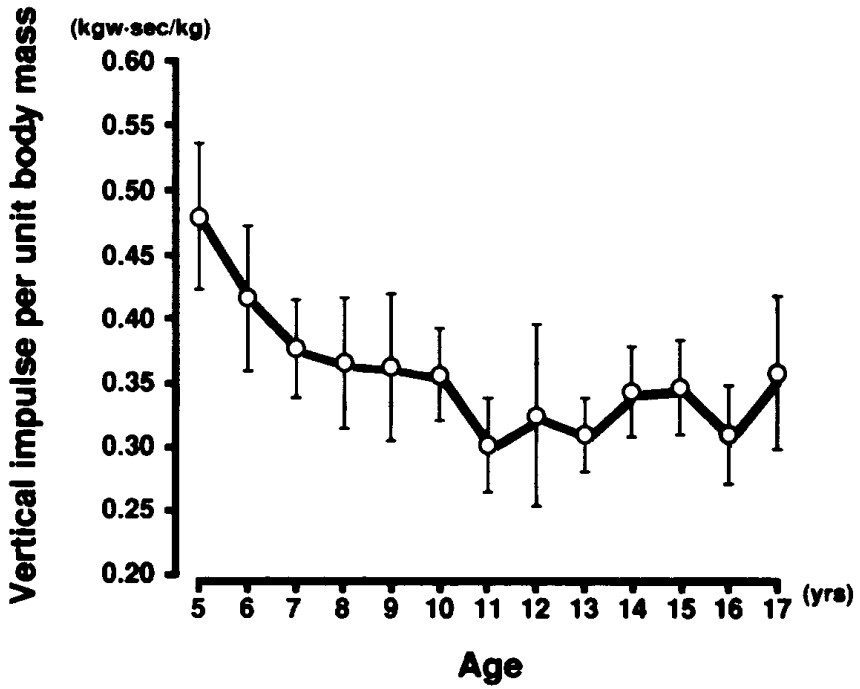

Fig. 8. Developmental change of vertical impulse per unit body mass.

(white circle : mean, vertical line : $s$. d.)

の間に $1 \%$ 水準の有意な増加，12荗と17歳の間に $1 \%$ 水準の有意な減少が認められた。17歳の単位 体質量あたりの水平力積を基準とすると， 5 歳の 值は69.6\%であった（Fig.9）。

\section{【噰镜】}

敏捷な切り換え動作の発達に関する研究は，反 復頻度を指標とした報告が多い。局所動作の tap. ping 動作では, 浅見と啮川 ${ }^{11}$ が 4 歳から 8 歳まで

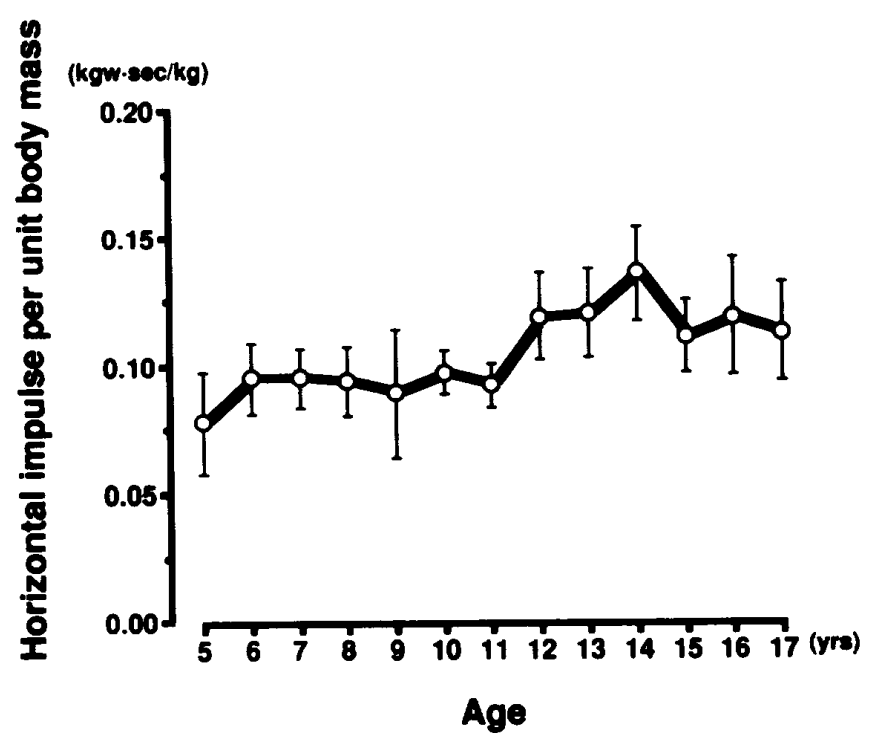

Fig. 9. Developmental change of horizontal impulse per unit body mass.

(white circle : mean, vertical line : s. d.) 
急激な回数の増加を示し，9歳以降ではゆるやか な発達になると報告し, 古屋 ${ }^{3)}$ は15・16歳で発達 が停止すると報告している. stepping 動作では, 4 歳から11歳まで渐次回数が増加するが, $11 ・ 12$ 歳以降に発達が停滞することが報告されてい $ろ^{1,22)}$. 全身動作の side step は, 3.9歳-4.8歳 の男子が20秒間に16.6回，11.4歳－12.3歳の男子 が44.4回であり，加龄にともなって增加するが， 幼稚園の年少・年中租ではテスト方法に対する理 解度が低く標準偏差が極端に大きくなることが指 摘されている1)。このように一般的に用いられて いる side step は, 小学校高学年以上を対象とし て作成された測定法であり，幼児や小学校低学 年・中学年を対象とする場合には問題がある。ま た side step の測定は，小学校高学年のライン幅 が $200 \mathrm{~cm}$, 中学生以上が $240 \mathrm{~cm}$ の二段階に設定 されており，この測定法では身長の影翌が大きく 関与することが考えられる. 従って, 本研究では, 幼児からの測定が可能であるとともに，年龄毎に 跳踓幅が設定されている side jump 測定動作と し，5歳から17歳に亘る幅広い年龄層を対象に， 全身の反復動作の発達要因を床反力曲線から検討 することにした。

幼児の side jump の反復頻度は, 男子の4.6歳 -5.0 藏が毎秒1.15回, 6.1歳-6.5藏が1.86回と 報告されている ${ }^{8)}$. 本研究における 1 回所要時間 から换算した side jumpの頻度は, 5 歳が2.20回, 6 墄が2.47回と先の報告に比較してやや高い值を 示したが,これは本研究の反復頻度の測定が力曲 線の最も円滑な切り換え動作を抽出して分析した ことによるものと考えられる. 幼児の side jump 中における着床時間は, 4 葴が $269 \mathrm{msec} \cdot 5$ 藏

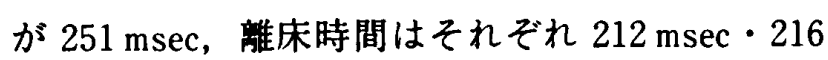
$\mathrm{msec}$ であり， 5 歳の着床時間が 4 歳に比較して 有意に短縮すると報告されている ${ }^{17)}$. 本研究に おける side jump の着床時間と離床時間は， 5 歳 から11歳頃まで加龄に伴い顕著な短縮を示し，12 歳以降は停滞する傾向を示した。また，17藏を基 準とした 5 藏の着床時間と離床時間は，それぞれ $126.6 \% \cdot 127.6 \%$ とほほ等しい值であった，従っ て，加踚にともなう反復頻度の増加は, 着床と離
床の両時間が同様の短縮過程をたどりながら発達 するものと考えられる。またここらの時間の加 龄的変化は，これまでに報告されている tapping， stepping, side step の反復頻度を用いた発達過程 と類似した結果である ${ }^{1,3,9.23)}$ 。

敏捷な切り換え動作の反復頻度と床反力の関係 は，幼览の side jump 動作では反復頻度と水平分 カとの間に有意な正の相関関係を示すことが報告 されている17)。本研究における単位体質量あた りの鉛直分力は， 5 歳から17歳までほほ類似した 值を示し，加龄に伴う顕著な変化は認められな かったが，単位体質量あたりの水平分力は 5 歳か ら12歳頃まで加㱓に伴い有意に増加し，17歳を基 準とした5歳の水平分力の比率 $(44.2 \%)$ は，鉛 直分力 $(90.0 \%)$ に比較して極めて低い值を示し た。また，鉛直分力と水平分力を合成して算出し たキック角度は, 5 歳から12歳まで有意に滅少し, 12歳以降は顥著な変化を示さなかった。これらの 結果は，幼児期における水平方向へのキック能力 が極めて未熟であることを示唆し，5歳から12歳 頃までの反復頻度の急激な増加は，水平分力の増 加によるものと考えられる。このことは水平分力 の增加にともなう切り換え動作の身体制御能力が 12歳頃まで著しく発達し，このことが反復頻度を 增加させる重要な要因になることを示唆してい る、また，この身体制御能力の発達の要因には， 上体の安定と下肢の角速度の増大が考えられる。

また，力積について観察すると，単位体質量あ たりの鉛直成分は， 5 歳から11歳頃まで加耣に伴 い有意に滅少し，11歳以降は停滞する傾向を示し た。この鉛直成分の滅少は，加龄にともなう単位 体質量あたりの鉛直分力が変化しないにも関わら ず着床時間が短縮することに起因している。一方， 単位体質量あたりの水平成分は，加龄に伴う影著 な変化を示さなかったが、これは加龄にともなう 着床時間の短縮と単位体質量あたりの水平分力の 増加とによるものである，さらに，17藏の力積を 基準とした 5 歳の鉛直成分と水平成分はそれぞれ $133.5 \%$ と $69.6 \%$ であり，この相対值は 11 藏頃ま でに接近する傾向を示した。このことは，加龄に ともなって鉛直方向への筋力発揮を水平方向への 
Table 3. Correlation coefficients between the time on the ground and ground reaction forces at each age.

\begin{tabular}{|c|c|c|c|c|c|c|c|c|c|c|c|c|c|}
\hline Age (yr) & 5 & 6 & 7 & 8 & 9 & 10 & 11 & 12 & 13 & 14 & 15 & 16 & 17 \\
\hline Vertical force & $\begin{array}{c}-0.876 \\
* * *\end{array}$ & $\begin{array}{c}-0.564 \\
*\end{array}$ & -0.429 & -0.351 & -0.399 & -0.420 & -0.078 & -0.304 & -0.349 & -0.189 & -0.435 & -0.292 & -0.336 \\
\hline Horizontal force & $\begin{array}{l}-0.677 \\
* * *\end{array}$ & $\begin{array}{l}-0.818 \\
* * *\end{array}$ & -0.401 & -0.325 & $\begin{array}{l}-0.770 \\
* * *\end{array}$ & $\begin{array}{c}-0.690 \\
* *\end{array}$ & -0.547 & $\begin{array}{c}-0.816 \\
* * *\end{array}$ & -0.128 & -0.611 & -0.432 & -0.338 & -0.401 \\
\hline Kicking angle & 0.003 & $\underset{*}{0.552}$ & 0.172 & 0.225 & 0.502 & 0.333 & $\begin{array}{l}0.544 \\
*\end{array}$ & $\begin{array}{l}0.750 \\
* * *\end{array}$ & -0.222 & $\begin{array}{c}0.472 \\
*\end{array}$ & 0.258 & 0.214 & 0.220 \\
\hline Vertical impulse & -0.096 & 0.424 & -0.258 & $\stackrel{0.569}{*}$ & 0.193 & 0.052 & 0.261 & $\begin{array}{l}0.668 \\
* * *\end{array}$ & 0.028 & 0.217 & -0.065 & 0.229 & $\begin{array}{c}0.589 \\
* *\end{array}$ \\
\hline Horizontal impulse & 0.107 & -0.132 & 0.080 & 0.382 & 0.029 & -0.022 & 0.041 & $0: 212$ & 0.625 & 0.225 & -0.011 & 0.507 & 0.632 \\
\hline
\end{tabular}

筋力発揮に切り換える能力が発達し, side jump 中に鉛直方向への重心移動の少ない切り换え動作 が可能になることを示唆している.以上の結果は, 急速な反復動作が加龄にともなって短時間に水平 方向への筋力発揮が增加し，このことがキック角 度を減少させ，上方への重心移動の少ない切り換 え動作となり，このような身体制御を含む切り換 え能力はおよそ12歳頃まで発達すると考えられ る.

本研究では，各年齢における切り換え動作の素 早さの要因を探るため, 着床時間および離床時間 と床反力との関係についての検討した (Table 3 ・ Table 4)。この結果, 着床時間はほとんどの年齡 における単位体犋量あたりの水平分力と有意な負 の相関関係を示し, 離床時間はほとんどの年龄に おけるキック角度と単位体質量あたりの力積の鉛 直成分との間に有意な正の相関関係を示した。こ
のことは，各年龄において素早い切り换え動作を 行うには，キック力を鉛直方向から水平方向へ変 换させ，力積の鉛直成分を滅少させたキック角度 の小さい跳躍動作が着床と離床の両時間を短縮さ せる重要な要因になることを示唆している。

本研究では，さらに各年龄における被検者の形 態・筋パワー・局所の反復動作と side jump の反 復頻度との関係を検討した（Table 5). その結果, side jump の反復頻度は， 7 歳・10歳・17歳の形 態と筋パワーとの間に一部有意な相関関係が認め られた。しかしながら， side jump の反復頻度は， ほとんどの年龄において形態や筋パワーとの間に 有意な相関関係を示していないことから，これら の有意性については，被検者のサンプリングによ る特異的なものと考えられる。筆者ら ${ }^{25)}$ は，こ れまでに成人を対象として, side jumpの反復頻 度が形態 (身長・体質量・下肢長・体脂肪率) p

Table 4. Correlation coefficients between the time in the air and ground reaction forces at each age.

\begin{tabular}{|c|c|c|c|c|c|c|c|c|c|c|c|c|c|}
\hline Age (yr) & 5 & 6 & 7 & 8 & 9 & 10 & 11 & 12 & 13 & 14 & 15 & 16 & 17 \\
\hline Vertical force & 0.387 & 0.043 & $\begin{array}{c}0.693 \\
* *\end{array}$ & 0.041 & $\begin{array}{l}0.635 \\
* *\end{array}$ & 0.395 & 0.382 & 0.305 & 0.484 & $\begin{array}{l}0.767 \\
* * *\end{array}$ & 0.141 & 0.370 & $\begin{array}{c}0.458 \\
*\end{array}$ \\
\hline Horizontal force & 0.114 & $\begin{array}{l}-0.720 \\
* * *\end{array}$ & $\begin{array}{c}-0.699 \\
* *\end{array}$ & -0.436 & 0.137 & -0.120 & -0.126 & -0.540 & 0.238 & 0.142 & 0.076 & 0.306 & 0.000 \\
\hline Kicking angle & 0.224 & $\begin{array}{l}0.897 \\
* * *\end{array}$ & $\begin{array}{l}0.842 \\
* * *\end{array}$ & $\underset{*}{0.569}$ & 0.380 & $\begin{array}{c}0.703 \\
* *\end{array}$ & $\begin{array}{c}0.673 \\
* *\end{array}$ & $\begin{array}{l}0.767 \\
* * *\end{array}$ & 0.182 & 0.336 & -0.009 & -0.012 & 0.366 \\
\hline Vertical impulse & 0.075 & $\begin{array}{l}0.849 \\
* * *\end{array}$ & $\begin{array}{l}0.920 \\
* * *\end{array}$ & $\begin{array}{l}0.932 \\
* * *\end{array}$ & 0.089 & $\begin{array}{c}0.697 \\
* *\end{array}$ & $\begin{array}{l}0.883 \\
* * *\end{array}$ & $\begin{array}{l}0.836 \\
* * *\end{array}$ & $\begin{array}{l}0.675 \\
* *\end{array}$ & $\begin{array}{l}0.759 \\
* * *\end{array}$ & $\begin{array}{l}0.889 \\
* * *\end{array}$ & $\begin{array}{c}0.690 \\
*\end{array}$ & $\begin{array}{l}0.899 \\
* * *\end{array}$ \\
\hline Horizontal impulse & -0.274 & -0.478 & -0.058 & 0.283 & $\begin{array}{c}0.528 \\
*\end{array}$ & -0.031 & 0.454 & 0.070 & $\begin{array}{c}0.447 \\
*\end{array}$ & 0.284 & 0.343 & 0.229 & $\begin{array}{c}0.476 \\
*\end{array}$ \\
\hline
\end{tabular}


Table 5. Correlation coefficients between the jumping frequency per second and physical characteristics.

\begin{tabular}{|c|c|c|c|c|c|c|c|c|c|c|c|c|c|}
\hline Age $(y r)$ & 5 & 6 & 7 & 8 & 9 & 10 & 11 & 12 & 13 & 14 & 15 & 16 & 17 \\
\hline Body height & -0.232 & -0.389 & 0.364 & 0.124 & -0.017 & $\begin{array}{c}-0.576 \\
*\end{array}$ & -0.003 & 0.079 & -0.326 & 0.157 & 0.146 & 0.075 & $\begin{array}{c}0.576 \\
* *\end{array}$ \\
\hline Body mass & -0.131 & -0.262 & 0.355 & 0.200 & 0.127 & $\begin{array}{c}-0.571 \\
*\end{array}$ & -0.057 & 0.013 & -0.142 & 0.091 & -0.127 & 0.296 & 0.392 \\
\hline Skinfold thickness & -0.140 & -0.111 & 0.114 & 0.145 & 0.191 & $\begin{array}{c}-0.562 \\
*\end{array}$ & -0.167 & -0.060 & -0.196 & -0.013 & -0.207 & 0.109 & 0.106 \\
\hline Vertical jump & -0.424 & 0.108 & $\begin{array}{c}0.658 \\
* *\end{array}$ & 0.391 & -0.288 & 0.087 & 0.333 & 0.406 & 0.007 & 0.241 & 0.332 & -0.442 & 0.306 \\
\hline Standing broad jump & 0.052 & 0.050 & 0.427 & 0.438 & -0.218 & 0.233 & 0.177 & 0.240 & 0.015 & -0.171 & -0.165 & 0.178 & $\begin{array}{c}0.472 \\
*\end{array}$ \\
\hline Stepping & 0.110 & ${ }_{*}^{0.513}$ & $\begin{array}{c}0.652 \\
* *\end{array}$ & -0.163 & -0.399 & 0.385 & 0.143 & 0.286 & -0.211 & -0.137 & 0.266 & 0.234 & 0.238 \\
\hline
\end{tabular}

筋出力（脚筋力・垂直跳び）との間に有意な相関 関係の認められないことを報告しており，本研究 もほとんどの年齢で一致した結果を示した。これ らの結果は，一般的には敏捷な全身の反復動作が 形態・筋出力に依存する要因ではなく, 筋出力の 大きさよりもこれらを制御する能力の重要性を示 唆している。また，反復動作における局所動作と 全身動作の関係については，これまでに両者の間 に有意な相関関係の認められないことが報告され ている ${ }^{25)}$. 本研究における side jump と stepping のとの間にもほとんどの年齢において有意な相関 関係を示さず，先の報告と同様の結果を得た。こ れについて猪飼 ${ }^{4}$ は，身体全体の取扱い (control over the body in general）と精細な取扱い（finer motor-skill）とは区別されることを指摘している. 従って, 全身の反復動作は, 局所の反復動作に必 要な相反神経支配の機能に加えて, 筋出力のコン トロール及び姿勢制御などの脳幹小脳系の関与が 重要であると考えられる.

\section{【要約】}

本研究は, side jump 中に発揮された床反力曲 線を指標として，全身的な反復動作の加龄的変化 について運動学的な観点から究明することを目的 とした，被検者は健常な5歳から17歳までの男子 246名であり，形態 (身長・体質量・皮下脂肪厚)， 瞬発力（垂直跳び・立ち幅跳び），敏捷性 (stepping・side jump) が測定された. side jump の測定は，force plate 上の 2 本の平行線（各年齢 における身長の標準值の 3 分の 1 に設定）をでき る限り素早く左右・交互に跳躍させた。 force plate から導出された side jump中の床反力曲線 は，鉛直分力と水平分力が記録できるようにした。 力曲線からは, 反復類度, 着床時間, 蜼床時間, 最大の鉛直分力と水平分力, 力積の鉛直成分と水 平成分を計測し，最大鉛直分力と最大水平分力を 合成してキック角度を算出した。

side jump の反復頻度は11墄頃まで加龄にとも なって有意に增加した，着床時間は，10歳頃まで 加齢に伴い有意に短縮し，11藏以降はほほ停膟す る傾向であった，離床時間は，7藏頃まで加齢に 伴い有意に短縮し，11墄以降はほほ停漫する傾向 であった，単位体質量あたりの鉛直分力は加龄に 伴う顕著な変化を示さなかったが，単位体質量あ たりの水平分力は，12歳頃まで加龄に伴う有意な 增加を示した。 キック角度は，12歳頃まで加齢に 伴う有意な減少を示した，力積の単位体質量あた りの鉛直成分は，11歳頃まで加龄に伴う有意な隇 少を示したが，単位体質量あたりの水平成分は顥 著な変化を示さなかった。

以上の結果から, 急速な反復動作は, 加齡にと もなって短時間に水平方向への筋力発揮が增加 し，このことがキック角度を滅少させ，上方への 重心移動の少ない切り換え動作となり，このよう な身体制御を含む切り換え能力はおよそ12歳頃ま で発達することが示唆された。 
【徱】

本研究は, 三重大学教育学部附属幼稚園・附属 小学校・附属中学校・三重県立津高等学校のご助 カのもとに遂行されたものである。ここに記して 深謝の意を表する。

\section{文蝴（References）}

1）浅見高明・涉川促二(1975)拥整力に関する研究(2) 一その発達傾向について一。体育科学 $3: 188-199$.

2）浅見高明・泚川促二・浅野勝己・藤田 厚・朝比奈 一男 (1976) フィールド・テストとラボラトリー・テ ストからみた調整力の検討。体育科学 4:123-141.

3）古屋 正(1960)成長期における Tapping 検査の成 转について．体育学研究 $5: 216$.

4）猪飼道夫(1951) 功作の巧さの研究. 体育の科学 1: $151-156$.

5）猪飼道夫・山川純子(1953) 反得功作に於ける動作の 乱れの筋電龱学的研究. 体育学研究 $1: 340-344$.

6）猪餇道夫・山川純子(1951) 急速反復功作における疲 労の現われ方. 体育学研究 $1: 168-173$.

7）石河利宽 - 清水達夫・勝亦私一（1976）幼坚を対象と した調整力トレーニンクの実験的研究(1)一体操種目 を中心とした造栜ブダラムの効果について一，体 育科学 $4: 189-194$

8）川上雅之・松原 考 -太田正和 (1982) 幼览 $(4-7$ 藏）の体力の総合的分析一䑤捷性および睡発力の発 達と知能の関係一。体育の科学 $32: 451-456$.

9）河崎英武 (1944)成長期に於ける急速反復運動能力に 関する調查研究．民族街生 $12: 290$.

10）金原 勇・高松 櫓・小松邦江・三浦望慶 (1968) 敬 しょう性トレーニングに関する基磁的研究（その1） 一最大敏しょう性の得られる諸条件について一，東 京教育大学スポーツ研究所報 $6: 25-45$.

11）金原勇・高松 燕・袖山 紜・広橋義一(1968) 敬 しょう性トレーニングに関する基磁的研究（その 2) 一敏しょう性の発育段階差・性差と敏しょう性卜 レーニングー，東京教育大学スポーツ研究所報 6 ： 46-54.

12）松井秀治・勝部篤美 (1974) 調整力テストの作成に関
する研究(1)一幼児用調整力テストの検討一。体育科 学 $2: 290-299$.

13）松井秀治・勝部䉆美 (1975) 調整カテストの作成に関 する研究(2)一幼坚・学童用調整力テストの検討一. 体育科学 $3: 174-184$.

14）松井秀治 - 勝部䉆美 - 水谷四郎 - 脇田裕久 (1976) 調 整力向上のための身体運動の練習効果について，体 育科学 $4: 158-169$.

15）飯塚鉄夫 - 日丸哲也・岩崎義正・永田 晨・唐津邦 利 (1968) 全身敏捷性テストとしての J.S.T.の研 究. 体育学研究 $13: 39-48$.

16）森下はるみ・佐々木玲子・鈴木俊朗 (1988) 幼児の打 吅動作拥節の発達。体育科学 16:99-110.

17）並木洋子 - 奥田隆行 ・脇田裕久 (1991) 幼坚のサイド ジャンブに関する研究. 東海保健体育科学 13:1522.

18）西沢 昭・浅見高明 (1978) 敏捷性の研究法につい て. 体育の科学 $28: 262-268$.

19）大道 等・八木尚江・森下はるみ(1983) 幼児夕ッピ ング動作の镜察. 体育の科学 33:240-247.

20）酒巻敏夫 (1974) 敏捷性測定法の検討. 体育の科学 $24: 250-252$.

21）体育科学センター（1976）調整力テスト実施要領およ びその基瀿値. 体育科学 $4: 207-217$.

22）徳山 展・荒木 勉・藤坂 弘・三野 耕・辻野 昭(1969) 急速反復動作（ステッピンク）の年龄別並 びに性別変化について．体育学研究 $13: 124$.

23）東京都立大学身体暗性学研究室編（1980）日本人の体 力標準值 (第 3 版)，不昧堂出版：東京, pp. 216-217.

24）湯浅累元 (1985) 文部省体力テストを解剖する，体育 の科学 $35: 444-450$.

25）脇田裕久・杉田正明・矢部京之助 (1990)下肢におけ る急速反復功作の検討. 赭合保健体育科学 13 ： 79-89.

26）矢部京之助 (1973) 体力要素としての敏捷性. 猪飼道 夫編著 身体運動の生理学. 杏林書院：東京, pp. 84-94.

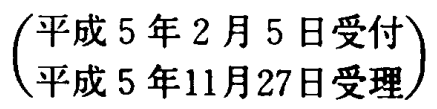

